\title{
Equality, Assurance and Criminalization
}

\author{
Vincent Chiao
}

Version Post-print/accepted manuscript

Citation Vincent Chiao, "Equality, Assurance and Criminalization" (2014) 27:1

(published version) Canadian Journal of Law \& Jurisprudence 5-26.

Publisher's Statement This is the peer reviewed version of the article: Vincent Chiao, "Equality, Assurance and Criminalization" (2014) 27:1 Canadian Journal of Law \& Jurisprudence 5-26. Copyright (C) [2014]. Reprinted by permission of the Canadian Journal of Law \& Jurisprudence. The final version can be found at https://doi.org/10.1017/s0841820900006202

\section{How to cite TSpace items}

Always cite the published version, so the author(s) will receive recognition through services that track citation counts, e.g. Scopus. If you need to cite the page number of the author manuscript from TSpace because you cannot access the published version, then cite the TSpace version in addition to the published version using the permanent URI (handle) found on the record page.

This article was made openly accessible by $U$ of $T$ Faculty. Please tell us how this access benefits you. Your story matters. 


\title{
Equality, assurance and criminalization
}

\author{
Vincent Chiao \\ University of Toronto \\ Faculty of Law ${ }^{1}$
}

The criminal law has at least two goals: to provide a degree of protection to a variety of individual and collective interests, and to communicate to those to whom it applies that those interests are protected. The question I shall consider is whether the criminal law should be used to advance the second goal independently of its use in advancing the first. I shall suggest that the answer is no.

In the first section of the paper, I sketch an argument for this claim and discuss the assumptions on which it rests. In the subsequent sections, I consider the implications of this argument for the criminalization of hate speech, and specifically a line of argument found both in the Supreme Court of Canada's jurisprudence as well as Jeremy Waldron's recent book, The Harm in Hate Speech. In the final section, I turn to examining a structurally similar, but broader argument - recently defended by Alon Harel - which suggests that there is a constitutional duty to criminalize conduct that would, if engaged in, interfere with a person's dominion over how her life goes, regardless of whether criminalization would or would not drive down the actual incidence of the targeted conduct. I claim that egalitarians should not recognize any such duty.

I.

I start with two assumptions, one substantive and one definitional. The substantive assumption concerns the content of a theory of just social institutions. In particular, I shall assume that reasonably just institutions should be egalitarian in the sense that they should ensure that each person under their jurisdiction has his or her basic interests sufficiently protected. I shall refer to these basic interests as "first-order interests," and I shall refer to this assumption as the assumption of non-comparative equality ("NCE"). For a noncomparative egalitarian, a person's first-order interests (a) pertain to a subset of basic liberties, capabilities or resources, namely (b) those to which each person has an equivalent claim as a matter of justice. What it means to say that each person has an equivalent claim to those interests as a matter of justice is that egalitarian social institutions should strive to provide a decent social minimum for everyone, and should not permit trade-offs that put some people below that minimum in order to benefit individuals who would be sufficiently well-off in any case.

It may seem paradoxical to refer to non-comparative equality as a form of egalitarianism, as saying that $A$ and $B$ are equal obviously connotes a comparison between the two. The air of paradox can, I hope, be dispelled by considering that it is not an abuse of language to say that treating $A$ and $B$ as equals means treating them as independent sources of value, each worthy of respect and entitled to due consideration of their

\footnotetext{
${ }_{1}^{1}$ My thanks to Mike Cahill, Stephen Galoob, Palma Paciocco, Dan Priel, Spencer Robinson and Ken
} Simons for detailed and helpful thoughts on this draft. 
fundamental interests; and that this is consistent with A and B having (or being provided with) widely divergent resources, capabilities, etc.. ${ }^{2}$

Not all of the interests a person might have, or even those that most or everyone might have, are first-order interests. ${ }^{3}$ Only those interests which are in some sense required by NCE qualify as first-order interests. Which interests are included depends on the specific form of egalitarian theory one espouses. First-order interests thus have a natural stoppingpoint beyond which, while they are still interests that people may wish to provide for, they lose their first-order character. For instance, a person may have a first-order interest in mobility, which plausibly includes the ability to walk through town without being molested. However, while she may also have a further mobility interest in being able to walk from one side of the country to the other, that degree of mobility would probably not qualify as a first-order interest.

What counts as a first-order interest will, inevitably, be to a certain degree culturally contingent, insofar as what it takes to live a life of equal respect among one's peers can vary across cultures. One possibility would be to look to a society's constitutional tradition for a concretization of what that society takes to be its first-order interests. For instance, American and Canadian constitutional traditions have specified first-order interests in terms of "life, liberty or property" and "life, liberty and security of the person," respectively. While these interests are defined in quite abstract terms, they are given more specific content by the courts in an incremental process of development. Of course, one can easily specify more and less expansive lists of first-order interests, and there seems to be no reason why specification of these interests should be drawn exclusively, or perhaps even predominantly, from legal traditions. In any case, I do not rely on any particular specification of which first-order interests people have, but rather on the concept of firstorder interests as a way of giving content to the political ideal of equality.

Any plausible specification of first-order interests will certainly fall well short of listing all the important interests that people have in the various aspects of their lives. One set of interests in particular will not be included among any specification of first-order interests. These are second-order interests - that is, interests people have in the public affirmation of their entitlement to first-order interests, whatever those may be. Second-order interests are thus interests in knowing that others know that your first-order interests are vigilantly protected by the state. Second-order interests are interests insofar as the public affirmation of first-order interests is valuable to those whose interests are affirmed; and they are second-order because their content is derived from the range of first-order interests protected by an egalitarian state.

\footnotetext{
2 NCE parallels Harry Frankfurt's sufficientarianism, with the caveat that while Frankfurt sees a focus on non-comparative status as in competition to comparative equality, I believe the concept of equality is capacious enough to encompass a non-comparative dimension. See Harry Frankfurt, "Equality as a Moral Ideal" (1987) 98:1 Ethics 21. For a more recent discussion of sufficientarianism and equality, see Philip Pettit, On the People's Terms (Cambridge: Cambridge University Press, 2012) at 88-89.

${ }^{3}$ I bracket the question here of whether those interests are best cashed out in terms of capabilities, resources, welfare or some other metric.
} 
Why might an interest in public affirmation be valuable? One explanation would be that the public affirmation of first-order interests turns out to promote the underlying firstorder interests themselves. This type of explanation grounds the value of second-order interests in terms of their contribution to first-order interests. A different kind of explanation for the value of second-order interests is that it is independently valuable to have the weight of one's interests be publicly asserted and officially recognized. This kind of explanation for second-order interests does not rest on an empirical claim about their contribution to promoting first-order interests; instead, it provides a basis for recognizing second-order interests as an independent type of interest - as valuable in their own right, not simply as a means for promoting other interests. In this paper, I shall predominantly be concerned with this latter kind of explanation for the value of second-order interests.

Turning now to my definitional stipulation, I shall define "criminal" sanctions as any state-imposed sanction that invades first-order interests. It is important at this point to bear in mind the limited nature of first-order interests. Although taking someone's money invades a person's interests, it is not probably not an invasion of her first-order interests unless the foreseeable result of doing so is to reduce her to penury or otherwise place her below the baseline set by NCE.

I note that my definitional assumption deviates from current practice, as some penalties currently labeled criminal - such as small fines or short periods of unsupervised probation - arguably do not invade a person's first-order interests, whereas other, non-criminal penalties - such as deportation and civil commitment - clearly do. Under my usage, "criminal" sanctions include the so-called "collateral consequences" of conviction, regardless of whether the courts happen to conceive of such consequences as "truly" criminal or not. This line-drawing exercise is important because the civil/criminal distinction is often used to allocate entitlement to a variety of procedural and adjudicative rights, such that the imposition of sanctions considered to be "criminal" are hedged in by a regime that is heavily biased against false positives even at a substantial cost in false negatives. People facing sanctions considered to be criminal, for instance, are entitled to subsidized legal representation, the presumption of innocence and proof beyond a reasonable doubt. In contrast, people facing sanctions considered to be non-criminal typically have only a comparatively more stripped-down set of procedural rights at their disposal. $^{4}$

However, since I do not specify a set of first-order interests here, I also do not specify exactly where to draw the line between criminal and non-criminal sanctions. The point of the stipulation is to indicate that, for my current purposes, the line between criminal and non-criminal sanctions is drawn solely in reference to state action that foreseeably invades a person's first-order interests. It is not my aim here to specify where that line should be drawn in particular contexts. ${ }^{5}$

4 This function of the civil-criminal distinction is particularly noticeable in the American context. See, e.g., Padilla v Kentucky, 130 S Ct 1473 (2010); Smith v Doe, 538 U.S. 84 (2003); Kennedy v Mendoza-Martinez, 372 US 144 (1963). It is also apparent in Canadian law, though to a lesser degree. See $R v$ Wigglesworth, [1987] 2 SCR 541, 45 DLR (4th) 235; Whaling v Canada (Attorney General), 2012 CarswellBC 3357, 292 CCC (3d) 502

5 I have defended this usage elsewhere; see Vincent Chiao, "Punishment and Permissibility in the Criminal Law," (2013) 32:6 Law and Philosophy 729. 
Having articulated these two assumptions, the central claim of the paper can be succinctly stated. To wit: it follows from these two premises that criminal sanctions should only be used when doing so is necessary to protect people's first-order interests. Of course, protecting first-order interests through the use of criminal sanctions may be expected to contribute to the promotion of other interests, including second-order interests. That is certainly to be welcomed; however, egalitarians - that is, those who subscribe to NCE should reject the use of criminal sanctions unless there is reason to believe that their use contributes materially to the protection of first-order interests.

The argument for this conclusion can be presented as follows:

(1) An egalitarian state should guarantee, to the extent possible, the first-order interests of each of its citizens.

(2) In imposing criminal sanctions, the state invades the first-order interests of some of its citizens.

(3) Therefore, an egalitarian state should only impose criminal sanctions when doing so is necessary to protect its citizens' first-order interests;

(4) In particular, criminal sanctions should not be used to advance citizens' secondorder interests where doing so does not also materially advance their first-order interests.

The first two steps restate my starting assumptions, and the fourth follows directly from the first three. The controversial parts of the argument are thus the validity of the inference suggested by (3), as well as whether NCE, encapsulated in premise (1), is an attractive and plausible premise. I first consider the inference, and then turn to briefly consider the premise that leads to it.

I believe that (3) is inescapable for egalitarians, at least insofar as they subscribe to NCE. This is because NCE seeks to ensure that social institutions protect each person's firstorder interests, whatever they are. Accordingly, as a first-best, non-comparative egalitarians would prefer that the state not impose criminal sanctions on anyone, as criminal sanctions are, by stipulation, those sanctions which invade first-order interests. The question then becomes: under what conditions, if any, should non-comparative egalitarians derogate from this principle and allow the state to impose criminal sanctions, thereby invading the first-order interests that it ostensibly guarantees to all?

There are two salient possibilities. First, NCE could allow the state to impose criminal sanctions when necessary to protect its citizens' first-order interests, e.g. by deterring or preventing conduct that invades first-order interests. Or, second, NCE could allow the state to impose criminal sanctions to further its citizens' other interests, including their secondorder interests, and independently of the impact that doing so would have on their firstorder interests. Let us first consider what the latter option would entail. While there is no doubt that interests other than first-order interests are of great value and significance in peoples' lives, and that an egalitarian state may be justified in expending significant resources in protecting and furthering these interests, if it were to do so by means of criminal sanctions it would in effect be denying some people the basic prerogatives of equal respect and concern in order to further the less basic interests of others - interests that are less basic from the point of view of NCE itself. Imposing criminal sanctions on people when doing so does not materially advance first-order interests, in other words, would be to 
allow trading off the first-order interests of some against the non-first-order interests of others. It follows from NCE that permitting a trade-off of this character would be tantamount to a failure by the state to show equal respect and concern to its citizens. It would to that degree be inconsistent with the prioritization of first-order interests that is the defining feature of NCE.

This leaves the possibility that the state could permit the invasion of some of its citizens' first-order interests only when doing so also protects other citizens' first-order interests, for instance by preventing or deterring conduct that would invade them. The use of criminal sanctions would obviously be less than ideal, given NCE's commitment to protecting everyone's first-order interests. However, a justification for criminal sanctions that is grounded in their contribution to protecting first-order interests would at least be consistent with the substance of NCE under non-ideal conditions. Deterrent sanctions, if reasonably necessary to achieving these egalitarian ends, would provide a central plank of an egalitarian framework for justifying a deviation from an egalitarian ideal. By the same token, precisely because criminal sanctions are a deviation from an egalitarian ideal, proponents of NCE have strong reason to be very cautious about using them to achieve speculative downstream goods. The point, however, is that this type of explanation stands in contrast to an explanation grounded in non-first-order interests, which attempts to justify a deviation from the egalitarian ideal in terms of interests that are not germane to non-comparative egalitarianism.

Against the argument sketched in the previous two paragraphs, it might be objected that a person who commits what amounts to a serious crime against another forfeits whatever entitlement he has to have his first-order interests protected. However, this view is inconsistent with the assumption of NCE because it is tantamount to allowing public institutions to invade a person's first-order interests, even when doing so is not necessary to protecting the first-order interests of others. A forfeiture theory would thus permit public institutions to invade interests that are central to NCE for the sake of interests that are not of central importance to NCE. While a non-comparative egalitarian may accept that criminal sanctions should be reserved for the guilty, she could not accept the forfeiture theory's further claim that establishing guilt is a sufficient basis for applying criminal sanctions, obviating the need for any further justification for the use of such a sanction. An egalitarian state has an interest in ensuring that its citizens and residents do not deprive each other of their first-order interests, and people who do so are likely to qualify as criminals under an egalitarian state's criminal law. But because criminal sanctions themselves deprive people of first-order interests, the degree to which this is so must be sensitive to difficult empirical questions about the practical necessity of such sanctions to creating and maintaining a baseline standard for all.

I note that the protection of first-order interests states a necessary, rather than a sufficient, condition for the use of criminal sanctions. When faced with a choice between criminal and non-criminal means for protecting first-order interests, public institutions committed to NCE should generally prefer the latter, on NCE grounds. When would NCE permit, or even require, the imposition of criminal sanctions? This is a difficult question, and I do not attempt to answer it here. A fuller explanation that I favor, but do not seek to defend here, is that an egalitarian state should invade the first-order interests of its citizens only when (a) other means for securing those interests are unreasonably costly, and (b) the costs of criminal sanctions are outweighed by their benefits, with both costs and benefits 
assessed in terms of first-order interests. Egalitarians might plausibly insist that in addition to protecting first-order interests, a fully adequate justification for imposing criminal sanctions would need to be consistent with respecting rights and provide a fair opportunity to comply with the law. For my immediate purposes, however, all I seek to defend is the claim that the protection of first-order interests makes out a necessary condition for the use of criminal sanctions from a non-comparative egalitarian point of view, even if it is not on its own sufficient.

The argument I have sketched can be obscured by the fact that, in real life, the use of criminal sanctions can be expected to simultaneously promote both first- and second-order interests. Thus, to sharpen the intuitive force of the argument, consider the following hypothetical scenario. Suppose that although everyone's first-order interests are sufficiently protected, the state does not rely on criminal sanctions to publicly convey that they are protected. Suppose, that is, that people's access to the basic resources and opportunities, rights and liberties, capabilities and welfare, and so on, are secured to an acceptable degree, and that information to this effect is reasonably available to those who wish to know; but that the state only prosecutes, convicts and sentences those guilty of crimes when doing so is expected to contribute to maintaining that level of protection. In particular, the state does not prosecute, convict and sentence those guilty of crimes simply to promote public awareness and appreciation of the proposition that everyone is entitled to have his or her first-order interests safeguarded. The question that step (3) of my argument poses is: does a state in this position have even a pro tanto reason to start using criminal sanctions for this end?

The answer for egalitarians must be "no." For if the state were to rely on criminal sanctions to further its citizens' second-order interests, i.e. to publicly communicate that it takes their first-order interests seriously, it would in effect be choosing a less egalitarian outcome over a more egalitarian one. For under the imagined status quo, everyone's firstorder interests are already reasonably well protected. Imposing criminal sanctions on some, even those guilty of crimes, would invade those interests without any countervailing benefit, as measured in terms of those interests. Therefore, choosing to do so would make the society less rather than more egalitarian.

As I have noted, first-order interests do not exhaust the interests that are important to people, or even the interests that public institutions may legitimately expend resources to promote. A person who has been victimized by a serious crime is likely to desire recognition of his victimization, as well as a symbolic reaffirmation of his status and the importance of his interests; and it might well be appropriate for an egalitarian state to take that desire seriously. My claim is only that the argument from NCE rules out doing so by means of deprivations that invade first-order interests, including those of the guilty party, absent an explanation consistent with NCE itself. To sum up the argument in a mildly tendentious manner, the claim is that egalitarian form should not trump egalitarian substance; people should not be locked up simply in order to make other people feel safer if doing so does not make them actually safer. ${ }^{6}$

${ }^{6}$ I am in a sense simply following HLA Hart's suggestion that while guilt might make someone eligible for punishment, it would not itself provide a reason for punishing him. See "Prolegomenon to the Principles of Punishment" in Punishment and Responsibility (Oxford: Oxford University Press, 2008) 1. 
Naturally, the strength of this argument depends on the strength of its assumptions. While I have articulated a particular conception of egalitarianism in non-comparative terms, I have not defended it, either as a fair representation of what most egalitarian political philosophers have in mind by the term, or on its own merits. ${ }^{7}$ There is a great deal of controversy about the precise contours of egalitarian political theory, to say nothing of the controversy concerning whether we should be egalitarians at all. I do not aim to contribute to that literature here. In large part, my aim is to draw connections between discussions of distributive justice and criminal justice - to show that there are important and under-theorized connections between the two. Assumptions about the contours of socalled "distributive" justice have direct consequences for criminal law and policy, including both criminalization and sentencing policy. The argument presented here has, I believe, significant purchase in the context of arguments, popular among both courts and legal theorists, that favor the use of criminal sanctions in order to convey expressive messages about the status and rights of those victimized by seriously wrongful conduct. More generally, much of the philosophically oriented discussion of criminal law over the last two to three decades has operated on an implicit assumption that the criminal justice system is a kind of exception to the ideals and values of egalitarian liberalism; that it, unlike society's other major legal institutions, somehow does not serve to distribute important and scarce social goods among a large class of claimants, but is rather (to put it crudely) an institutionalization of everyday, interpersonal morality. The argument from noncomparative equality is meant, in part, to show that insofar as the criminal justice system has a significant impact on those aspects of peoples' lives that matter to theories of socalled distributive justice, those institutions are profitably assessed within the terms of those theories. ${ }^{8}$

This being said, I do not think that my substantive assumption of NCE is adventitious. To the contrary, the account of egalitarianism I have relied upon captures what I take to be an important part of the motivation for much egalitarian political theory as well as, I suspect, many egalitarian social movements. NCE focuses on the thought that a society shows equal respect and concern for its members by ensuring that each of its members does sufficiently well along one or more indicia of basic human flourishing. NCE neither affirms nor contradicts the more controversial view that focuses on the value of comparative equality among citizens - for instance, views that value strict equality in entitlements. Presumably, egalitarians who believe that equality in distribution is valuable in itself would also believe, or at least would not take issue with, the view that ensuring that each person's basic interests are protected to some minimum degree is also a plausible egalitarian value, even if it is not the only one. While egalitarians might differ among themselves as to the conditions under which a person may gamble away his basic entitlements in voluntary exchanges, presumably even luck egalitarians could accept NCE's commitment to ensuring that each person's basic interests are appropriately safeguarded

\footnotetext{
${ }^{7}$ NCE is a controversial view, and faces serious challenges, particularly regarding policies that put people just below the threshold while achieving massive gains for people above the threshold. However, my aim here is not to defend NCE but rather to draw out some of its implications so, having noted them, I shall not consider these challenges further.

${ }^{8}$ For elaboration of this line of thought, see Vincent Chiao, "Against Punishment" [unpublished MS].
} 
against the predations and whims of others. ${ }^{9}$ NCE represents a position that is both substantive and of broad intuitive appeal, but it is also widely compatible with a range of more fully specified egalitarian theories.

I now turn to illustrating the implications of the argument from NCE. I focus on three contexts: first, a line of precedent in the Supreme Court of Canada's hate speech jurisprudence, re-articulated in its recent Whatcott opinion; second, a parallel line of argument defended by Jeremy Waldron in the context of hate speech; and, third, a broader account of criminalization as expressive anti-domination, articulated by Alon Harel. I argue that non-comparative egalitarians should be wary of each of these arguments, insofar as they privilege egalitarian form over egalitarian substance by suggesting that second-order interests could be a sufficient basis for the use of criminal sanctions.

II.

A.

In a landmark decision handed down in 1990, the Supreme Court of Canada affirmed the validity of s. 319(2) of Canada's Criminal Code, a statute that penalized the willful promotion of hatred against an identifiable group by up to two years' imprisonment. ${ }^{10}$ James Keegstra was a high school teacher in a rural Alberta community who disseminated a variety of anti-Semitic statements among his students, and insisted that they parrot back his sentiments on their assignments. Keegstra was fired in 1982, and was subsequently prosecuted under s. 319(2). The Court, in a majority opinion authored by Dickson, CJ., ultimately rejected Keegstra's argument that the statute impermissibly violated his "freedom of thought, belief, opinion and expression" under section 2(b) of the Canadian Charter of Rights and Freedoms, holding that while the statute limited his freedom of expression, the limitation was "demonstrably justified" in a free and democratic society.

In Keegstra, the Court articulated two rationales for criminalizing hate speech, or what it referred to as hate propaganda. The first line of thought focused on the "emotional damage" suffered by targeted individuals, damage which could carry "grave psychological and social consequences." 11 The opinion repeatedly emphasized its solicitude toward the emotional state of those targeted by hate propaganda. For instance, the Court's analysis of the harm engendered by hate propaganda focused on the victim's likely "response of humiliation and degradation," and the effect on his or her "sense of human dignity and belonging" as well as "self-worth and acceptance."12 Similarly, the Court found that

${ }^{9}$ See Elizabeth Anderson, "What is the Point of Equality?" (1999) 109:2 Ethics 287.

$10 R$ v Keegstra, [1990] 3 SCR 697, 124 DLR (4th) 289 [Keegstra cited to SCR]; Criminal Code, RSC 1985, c C-46, s 319(2). The statutory scheme identified the following as protected groups: "any section of the public distinguished by colour, race, religion, or ethnic origin" (ibid, s 319(7), s 318(4) as cited in Keegstra at para 7). The current version of the scheme adds as a protected group those distinguished by sexual orientation (ibid, s 319(7), s 318(4)).

${ }^{11}$ Keegstra, supra note 9 at para 64; see also para 114 (referring to "severe psychological trauma suffered by members of those identifiable groups targeted by hate propaganda.")

12 Ibid at para 61. 
Parliament, by enacting s. 319(2), was "trying to prevent the pain suffered by target group members and to reduce racial, ethnic and religious tension in Canada." 13 The Court found the use of criminal sanctions, rather than potentially less onerous penalties, to be justified because "the many, many Canadians who belong to identifiable groups surely gain a great deal of comfort from the knowledge that the hate-monger is criminally prosecuted and his or her ideas rejected." 14

The second rationale sketched in Keegstra did not rest on preventing psychological harm to individuals, but instead focused on the symbolic significance of punishing hate propaganda. Criminalizing the dissemination of hate propaganda "send[s] out a strong message of condemnation"; it ensures that "the community as a whole is reminded of the importance of diversity and multiculturalism in Canada, the value of equality and the worth and dignity of each human person being particularly emphasized." 15 This rationale invites two possible interpretations: a causal interpretation and a counter-speech interpretation. ${ }^{16}$

On the causal interpretation, punishing hate propaganda promotes diversity and multiculturalism by causally contributing to a decrease in the incidence of downstream acts of discrimination, bias crimes, social ostracism and the like. The difficulty with this rationale for regulating hate speech is that the Court did not cite any studies establishing that criminalizing hate speech has this effect, and in any case it appears that very few such studies exist. ${ }^{17}$ In R. v. Taylor, a companion case to Keegstra, the Court relied on a series of government and third-party reports for the proposition that, in addition to "substantial psychological distress" and "intensely painful reaction," hate propaganda

can operate to convince listeners, even if subtly, that members of certain racial or religious groups are inferior. The result may be an increase in acts of

\footnotetext{
13 Ibid at para 80.

14 Ibid at para 100.

15 Ibid at paras 136, 105. McLachlin J, writing for the dissenters, suggested that whatever expressive value might come from prosecutions under s 319(2) would have to be balanced against the extensive (and free) publicity that they would bestow upon hate groups (ibid at paras 301-05).

16 For a parallel discussion in the context of pornography, see Wayne Sumner, The Hateful and the Obscene (Toronto: University of Toronto Press, 2004) ch 5.

17 In contrast to pornography, there appears to be very little published research on the causal impact of hate speech. Sumner found no cross-sectional, longitudinal or laboratory studies on the topic. Ibid at 158-159. But see Brian Mullen \& Diana R Rice, "Ethnophaulisms and Exclusion: The Behavioral Consequences of Cognitive Representation of Ethnic Immigrant Groups” (2003) 29:8 Pers Soc Psychol Bull 1056 (reporting association between negative representation of 19 European ethnic groups and a variety of indicia of social exclusion, including intermarriage, membership in fraternal organizations, residential segregation, employment discrimination, naturalization rates and immigration quotas); Brian Mullen \& Joshua M Smyth, "Immigrant Suicide Rates as a Function of Ethnophaulisms: Hate Speech Predicts Death" (2004) 66:3 Psychosomatic Medicine 343 at 34446 (finding correlation between negative representation of European ethnic groups and suicide rates).
} 
discrimination, including the denial of equal opportunity in the provision of goods, services and facilities, and even incidents of violence. ${ }^{18}$

However, while anecdotes abound, and while it is easy to speculate about plausible causal pathways, none of the reports cited in Taylor provided any actual evidence of downstream harms caused by hate propaganda.

Naturally, lack of evidence of harm is not evidence of a lack of harm; and, more to the point, no argument has been given to establish that appellate courts ought to strike down legislation simply because the legislation is not supported by evidence. ${ }^{19}$ A more aggressive standard than usual might be appropriate in contexts where the state is seeking to invade an individual's first-order interests, but an argument would have to be given for this claim. (It certainly does not follow from the argument from NCE.) In other words, the suggestion is not that the Court necessarily reached the wrong outcome in Keegstra, but rather that the Court provided no evidence to support the hypothesis that hate propaganda, left unchecked, increases the incidence of social ostracism, bias crimes and so forth, suggesting a fairly deferential posture vis-à-vis Parliament's perception of harm.

However, the significance of criminalizing hate speech can be given a different, noncausal, interpretation. This is the suggestion that punishing hate speech sends a message of tolerance, and is valuable simply as a reaffirmation of Canada's commitment to egalitarian ideals. Since this rationale does not rest on an empirical basis, it would not be undermined even by decisive evidence that de-regulating hate speech would result in no significant increase in downstream harm to targeted groups. The point of punishing people for hate speech is to avow, in a public and demonstrative way, just how seriously Canada takes its egalitarian ideals. ${ }^{20}$

The contemporary Court appears to have essentially abandoned Keegstra's emphasis on the emotional harms of hate speech, even while it has retained some combination of both the causal and expressive rationales. In its recent decision, Saskatchewan (Human Rights Commission) $v$. Whatcott - a case involving an individual who distributed homophobic flyers around Regina and Saskatoon - the Court unanimously upheld a provision of Saskatchewan's human rights code that prohibits the publication or display of any representation that "exposes or tends to expose to hatred, ridicules, belittles or otherwise affronts the dignity of any person or class of persons on the basis of a prohibited ground," albeit only after insisting on a somewhat narrowed interpretation of the statute. ${ }^{21}$ In Whatcott, the Court minimized its earlier references to psychological harm to individuals, and focused instead on the impact of hate speech on the "societal standing" of the targeted groups. Hate speech, the Court claims, "lays the groundwork for later, broad attacks on

18 [1990] 3 SCR 892 at para 40, 75 DLR (4th) 577 [Taylor].

${ }^{19}$ For a defense of appellate deference to agency decisions taken under conditions of genuine uncertainty, see Adrian Vermeule, "Rationally Arbitrary Decisions (in Administrative Law)" Harvard Public Law Working Paper Series (25 March 2013) online: Social Science Research Network <http://papers.ssrn.com/sol3/papers.cfm?abstract_id=2239155>.

${ }^{20}$ Keegstra, supra note 9 at para 101.

21 Saskatchewan Human Rights Code, SS 1979, c S-24.1, s 14(1)(b); Saskatchewan Human Rights Commission v Whatcott, 2013 SCC 11, 355 DLR (4th) 383. 
vulnerable groups," attacks that could "range from discrimination, to ostracism, segregation, deportation, violence and, in the most extreme cases, to genocide". ${ }^{22}$ While the opinion is couched in causal terms, the targeted effects of unchecked hate speech are not limited to bias crimes, employment discrimination or other such exclusionary acts. Rather, hate speech will cause targeted groups to become less inclined to participate "in the deliberative aspects of our democracy." 23 The focus of the Court's analysis is not on the emotional impact of hate speech, but rather

on the likely effect of the hate speech on how individuals external to the group might reconsider the social standing of the group. Ultimately, it is the need to protect the societal standing of vulnerable groups that is the objective of legislation restricting hate speech. ${ }^{24}$

Accordingly, the Court struck out the statute's reference to expression that "ridicules, belittles or otherwise affronts the dignity of" a protected group, leaving only its application to publications that tend to expose protected groups to "hatred." The Court interpreted "hatred" as "extreme manifestations" of "detestation" and "vilification," and thereby considered the prohibition to be directed at speech that "incite[s] the level of abhorrence, delegitimization and rejection that risks causing discrimination or other harmful effects." 25 Speech that is merely "repugnant and offensive" does not fall within this categorization; rather, "[h]ate speech, is at its core, an effort to marginalize individuals based on their membership in a group." 26 In the end, the Court upheld the narrowed version of the statute as a prohibition on the publication or display of a representation that a reasonable person, "aware of the context and circumstances," would view as exposing or tending to expose "any person or class of persons to detestation and vilification on the basis of a prohibited ground of discrimination."27

B.

Before considering the merits of the Supreme Court of Canada's approach to hate speech in light of the argument from NCE, it is worth noting that the Court is in very good philosophical company. In a recent book, Jeremy Waldron has defended hate speech legislation in terms that largely track the Supreme Court of Canada's focus in Keegstra and Whatcott on the egalitarian message conveyed by such legislation, particularly on an expressive, rather than causal, interpretation of those cases. ${ }^{28}$ Like the Court, Waldron

22 Ibid at paras $74,82$.

${ }^{23}$ Ibid at para 75.

${ }^{24} \mathrm{Ibid}$ at para 82.

25 Ibid at para 57.

${ }^{26} \mathrm{Ibid}$ at paras $57,71$.

27 Ibid at para 95.

${ }^{28}$ Jeremy Waldron, The Harm in Hate Speech (Cambridge: Harvard University Press, 2012).

Waldron actually cites Keegstra in developing his concept of assurance (ibid at 84-85). 
focuses on a type of social harm that results from hate speech and that is independent of (though by no means exclusive of) the creation of subsequent harms from criminal victimization or discrimination. Waldron argues that regulating hate speech promotes the valuable public good of "assurance." Assurance is the confidence that people, particularly members of minority groups, have that "when they leave home in the morning, they can count on not being discriminated against or humiliated or terrorized." ${ }^{29}$ Like clean air or water, assurance is a public good in the sense that it is equally available to all as part of the taken-for-granted background in a well-functioning society.

Framed in this way, of course, the notion of assurance seems innocuous, even trite: protecting people from being discriminated against in housing, employment and public accommodations is a well-recognized use of law. The criminal law serves this purpose as well, insofar as it protects people from being assaulted, stalked or harassed, whether on account of their race, sexual orientation or for any other reason. However, assurance for Waldron extends beyond protecting these first-order interests; regulation of hate speech, Waldron insists, can be justified independently of any causal link between hate speech and discrimination or terrorization. Hate speech attacks the "dignitary order of society," and the government is justified in suppressing those attacks, regardless of whether or not they casually contribute to any harm to other sorts of interests. ${ }^{30}$ Unsurprisingly, then, Waldron resists the term "hate speech" both because it connotes a focus on the speaker's attitudes or motivations rather than the responses engendered by the speaker's actions and because the most damaging instances caught by the term are not fleeting instances of speech per se but rather "the published word or the posted image" - that is, expression that is more likely to find a wide audience than speech. ${ }^{31}$

Waldron argues that assurance is a particularly fragile public good. Even if most of the time, for most people, it is automatic and implicit, seemingly isolated flare-ups have a disproportionate impact on vulnerable groups by throwing into doubt whether they are not in fact naive in supposing that their neighbors and acquaintances are not closeted homophobes or racists. The burning cross, Waldron suggests, is meant to reveal that our superficially egalitarian society hides a darker reality; it is meant to publicly convey the message that

I know you think you are our equals. But don't be so sure. The very society you are relying on for your opportunities and your equal dignity is less than whole-hearted in its support for these things, and we are going to expose that half-heartedness and

\section{Ibid at 84.}

30 Ibid at 91-92, where Waldron compares his approach to MacKinnon's discussion of the causal contribution of pornography to violence against women, and identifies a "deeper issue" - that of the "dignitary order of society" - that is independent of the causal argument (ibid at 97-99).

31 Ibid at 34-39; the quoted phrase is on 37-8. Waldron does consider the impact of racist radio broadcasts during the Rwandan genocide; see ibid at 71-72. However, the distinction between (relatively permanent) visual representations and (relatively ephemeral) speech might be questionable in the era of smartphones and YouTube, which make it possible to record and upload the most fleeting of remarks for consumption on a worldwide scale. For a related discussion, albeit in the context of obscenity, see Leslie Green, "Obscenity Without Borders" in François TanguayReynaud \& James Stribopoulos, eds, Rethinking Criminal Law Theory (Oxford: Hart, 2012) 75. 
build on that ambivalence every chance we get. So: think about it and be afraid. The time for your degradation and your exclusion by the society that presently shelters you is fast approaching. ${ }^{32}$

Even if this kind of hateful message is an empty threat and has no real prospect of affecting anyone's actual social standing or security, the message itself is chilling and destabilizing. Assurance is impaired even if such messages are both factually false (the speaker speaks for no one other than himself) and causally inert (it does not actually contribute to increasing the likelihood of downstream harms). Those targeted by such messages may feel less confident in their security and status regardless; the function of hate speech legislation is to prevent this erosion of assurance. ${ }^{33}$

At the same time, Waldron, like the Supreme Court of Canada in Whatcott, is at pains to explicitly distinguish hate speech's impact on assurance from mere offense. Hate speech is not, or not simply, speech that is wounding and contemptuous. Of course, expression that attempts to suggest the marginalization of this or that group of people is likely to arouse intense feelings on the part of those on the receiving end of such vitriol. But the regulation of hate speech is no more targeted at the subjective experience of hate speech than (to carry forward Waldron's analogy to public goods) the regulation of water pollution is targeted at the subjective experience of drinking fouled water.

C.

The arguments just canvassed provide an illuminating case study of the impact of the egalitarian argument sketched in part I. I believe that we do not find, either in the Supreme Court of Canada's jurisprudence or in Waldron's recent discussion of hate speech, a justification for the criminalization of hate speech that is consistent with NCE. ${ }^{34}$ Both the Supreme Court of Canada and Waldron emphasize what I have characterized as secondorder interests, namely the interest in seeing one's first-order interests publicly affirmed as such. But the argument from NCE, if sound, shows that sanctions that invade first-order interests cannot be justified by appeal to an enhancement to second-order interests alone. Insofar as its explanation of the permissibility of enforcing hate speech legislation with criminal sanctions rests on the sheer communication and avowal of egalitarian values, the Supreme Court of Canada has placed the second-order interest in knowing that other people know about one's status as an equal above the protection of actual equality, i.e. the protection of everyone's first-order interests - including the first-order interests of homophobes and bigots. By the same token, the interest in assurance as Waldron conceives of it is an interest that people have in believing that their first-order interests - their actual

\footnotetext{
32 Waldron, supra note 27 at 96.

33 Ibid at 92-96.

34 Waldron's concern lies predominantly with the rights-based arguments about free speech, whereas my concern lies predominantly with the criminalization of hate speech. That said, Waldron takes criminal libel statutes as his model for group defamation. Criminal libel statutes were used by states to keep the peace, not just to secure private individuals' reputations. Waldron, supra note 27 at $\operatorname{ch} 3$.
} 
ability to live their lives in society's major institutions free of discrimination, ostracism and violence - are protected. Therefore, criminalizing hate speech in order to assure the wouldbe targets of such speech is inconsistent with NCE, unless doing so does not simply convey a social judgment but also actually enhances the protection of the underlying first-order interests.

It is worth noting here what the argument purports to show, and what it does not. First, the argument that egalitarian public institutions ought not use criminal sanctions to convey messages of toleration or to protect people from the fear that they might be victimized is not grounded on a conception of the scope of the right to free expression. In particular, it is not grounded in the concept of viewpoint neutrality associated with American First Amendment jurisprudence. It would be consistent with the argument from NCE to place a wide range of non-criminal sanctions on hate speech. It would also be consistent with the argument from NCE to insist that no such sanctions should be allowed, on grounds of viewpoint neutrality. As I have noted, the argument is meant to provide a necessary condition for the use of criminal sanctions, not a sufficient one. NCE thus distinguishes between Keegstra - in which the challenged statute authorized a period of two years' imprisonment - and Whatcott, in which only relatively modest financial penalties were at stake. The argument from NCE is concerned with the nature of the remedy, not the scope of the right.

Secondly, the critique is narrow in another dimension as well. It is targeted at the expressivist rather than causal interpretation of the rationale for criminalizing hate speech. If criminalizing X in fact contributes materially to protecting people's first-order interests, then the criminalization of X is consistent with the argument from NCE, subject to whatever further constraints on criminalization one might find applicable (perhaps grounded in a conception of the right to free expression.) What renders the expressivist arguments for criminalizing hate speech problematic from the point of view of NCE is their complete indifference to the contribution of criminal sanctions to the actual protection of peoples' first-order interests. The expressive value of criminalizing hate speech does not, after all, depend on the speculative hypothesis that doing so will actually protect others from future discrimination and violence. However, from the point of view of NCE, the existence of a plausible, empirically sound basis for linking hate speech to downstream invasions of firstorder interests would provide a good pro tanto reason for criminalizing such conduct, whereas a purely expressive rationale - no matter how noble the message conveyed would not.

What would such proof of downstream harm look like? Waldron criticizes opponents of hate speech regulation for demanding a one-to-one accounting: that any particular instance of hate speech would, if left to its own devices, lead to a particular crime or discriminatory act. ${ }^{35}$ Waldron instead analogizes the harm in hate speech to environmental harm: no single act may be significant in itself, but taken in the aggregate it can add up to very serious harm indeed. ${ }^{36}$

I agree with Waldron that policy decisions about hate speech must look at the consequences of a type of conduct in the aggregate, rather than on a case-by-case basis.

35 Waldron, supra note 27 at 96-97.

36 Ibid at 97. 
However, whether the analogy to environmental harms is tenable requires a judgment about empirical conditions that Waldron does not acknowledge, much less address in any detail. In particular, whether a type of conduct leads to sufficient harm in the aggregate to warrant the expected costs of regulating it depends on an estimation of how much of that conduct we should expect to occur absent regulation. For example, if there are only 100 cars in existence, then not only does no single car inflict significant environmental damage, all of them taken together fail to do so as well. This state of affairs would significantly weaken the case for regulating automobile emissions. In the context of hate speech, the question that must be addressed - and which is ignored by both Waldron and the Supreme Court of Canada - is whether, absent such legislation, hateful propaganda would in fact proliferate to such a degree that it would be plausible to believe that significant downstream harm would result. Perhaps the answer is clearly yes; the point is that it is an empirical question, not one that can be decided by philosophical or judicial fiat. ${ }^{37}$ For Waldron's analogy to environmental harm to work, in other words, we must be confident that but for the criminalization of hate speech, what is now the occasional homophobic flyer or racist diatribe would proliferate to such an extent that the overall social atmosphere will become one in which acts of discrimination and violence become significantly more likely. Perhaps there are societies about where this is plausible: perhaps Rwanda in the mid-1990s, or Eastern Europe at various points in the $20^{\text {th }}$-century, or Uganda today, meet this standard. But while it is surely not the case that Canada, the United States and Western Europe have entirely broken free of their legacies of racism, homophobia and so forth, it is also not very plausible to think that failure to imprison the occasional anti-Islamist bigot, homophobe or racist is likely to seriously set back the cause of social justice in these countries. ${ }^{38}$

Non-comparative egalitarians could support criminalizing hate speech, even in the absence of downstream harms, if protecting people from the offense or emotional distress caused by hate speech were itself a first-order interest. That is, the harm in hate speech

\footnotetext{
37 In Keegstra, supra note 9 at para 114, the majority refused to require proof that hate speech causes an increase in hateful sentiments among the public because proving a "causal link" would be too difficult and because it was already established that Parliament could "use the criminal law to prevent the risk of serious harms." A better rationale for the outcome in Keegstra might, accordingly, have been one of judicial deference to Parliament's prerogative to act in advance of empirical evidence.

38 Robert Mark Simpson argues in a similar vein that Waldron's attempt to bracket the actual impact of hate speech on conduct renders assurance too thin to bear the weight that Waldron assigns it. As Simpson puts it, "[w] hat has gone awry, when assurance fails, is that people cannot reasonably count on not being discriminated against, humiliated, or terrorised. If hate speech was not backed by genuine prejudice or hostile intentions - if it was merely superficial, offensive abuse - then it seems doubtful that people's sense of assurance of their status would be seriously threatened. Hate speech gets its potency, in real life cases, from the fact that it does reflect a deeper, sinister current of identity-oppressive intention. But then it is surely this underlying state of affairs - the fact that there are people who genuinely feel the contempt they express in hate speech, and who would be prepared to act on it - which puts people in a position such that they cannot reasonably count on not being discriminated against, humiliated or terrorized." "Dignity, Harm and Hate Speech," (2013) 32: 6 Law and Philosophy 701.
} 
could be a harm against a first-order interest if a society opts to recognize psychological or emotional well-being as a fundamental protected interest. The experience of waking in the middle of the night to find a cross burning on one's front lawn is very hard to imagine, and it is not implausible that a liberal society might seek to protect its citizens from that kind of distress, regardless of whether such expression causes any downstream harm - or, for that matter, whether it seriously affects the level of assurance people have in their social standing, or their fear that they might later be subject to violence and discrimination by their neighbors. ${ }^{39}$ Such an approach would, of course, raise concerns about whether liberals can countenance freedom from offense as a first-order interest. ${ }^{40}$ But, assuming those concerns could be met, it would at least provide a justification for criminalizing hate speech that is consistent with non-comparative egalitarianism.

Be that as it may, however, both Waldron and the Supreme Court of Canada reject this approach. Waldron explicitly rejects the offense principle: unlike dignity, "offense, however deeply felt, is not a proper object of legislative concern." ${ }^{41}$ Similarly, in Whatcott the Supreme Court rejected its earlier emphasis in Keegstra on the emotional reactions of those targeted by hate speech. "The feelings of the publisher or victim," the Court insisted, "are not the test." 42 The "test" is rather the impact of hate speech on the "societal standing" of the targeted groups. As with Waldron, the Court's focus is squarely on assurance and the message of equal dignity, not emotional distress per se. ${ }^{43}$

Why not accept the offense principle? Waldron argues that while offense is "inherently a subjective reaction," dignity is objective, in the sense that it concerns a person's standing vis-à-vis her peers, independently of how she happens to feel about it. ${ }^{44}$ Thus, although criticizing politicians who subscribe to a particular political ideology as foolish and extremist, or predicting disaster should they be elected into office, might be personally offensive to them, such criticism would not deprive them of assurance of their equal status and hence could not be regulated on grounds of providing assurance. On the other hand, "it would be inconsistent with the respect demanded by their status as citizens to publish a claim, for example, that Tea Party politicians cannot be trusted with public funds or that they are dishonest." The maligned politicians, Waldron avers, ought to be able to recover from someone who publishes such a statement "because that would be a scurrilous attack on what I have called their elementary dignity in society." 45

\footnotetext{
39 It might also be prohibited insofar as it evinces an intent to intimidate, rather than a contentbased regulation of speech. See Virginia v Black, 538 US 343 (2003) at 362.

${ }^{40}$ See especially Joel Feinberg, Offense to Others (New York: Oxford University Press, 1988).

41 Waldron, supra note 27 at 105.

42 Whatcott, supra note 20 at para 82.

43 The Court has, in the context of child custody proceedings, recognized "psychological integrity" as a protected interest under section 7 of the Charter of Rights and Freedoms. See New Brunswick (Minister of Health and Community Services) v G (J), [1999] 3 SCR 46, 177 DLR (4th) 124.

44 Waldron, supra note 27 at 106-07.

45 Ibid at 121.
} 
The example is a telling one, precisely because its emotional impact is so mild. Presumably, the rhetorical point here is to underscore the difference between speech that viscerally offends on the one hand, and speech that actually affects the assurance of equal standing on the other. At other points, however, Waldron relies upon examples where the emotional temperature is noticeably higher. Thus, for instance, he starts his book with the image of a Muslim father and his two young children confronting signs equating Muslims with terrorists, and later, in illustrating his concept of assurance, Waldron draws on a similar image by referring to President Lyndon Johnson's statement, made in defense of the 1964 Civil Rights Act, that "[a] man has a right not to be insulted in front of his children." 46 Assurance, Waldron tells us at these points, is meant to secure people against the "ugliness and distress" of just this kind of discriminatory interaction. ${ }^{47}$ It is not clear how seriously we are to take this, however, given his subsequent insistence that assurance is about protecting "elementary dignity" rather than emotional heat and offense. By abandoning offensiveness in favor of the protection of the "dignitary order of society," Waldron appears to be committed to the view that anti-hate speech legislation should reach a person who puts up placards calling a politician a liar for the same reason that it reaches someone who burns crosses or equates Muslim children with terrorists.

I express no view as to whether offense should or should not be considered to be a firstorder interest. However, denying that it is makes it significantly harder for Waldron, and the Supreme Court of Canada after Whatcott, to explain why criminal sanctions should be an available avenue for the regulation of hate speech. ${ }^{48}$ Brian Leiter, in a critical review of Waldron's book, asks rhetorically whether Waldron's defense of the dignitary order of society is "just Miss Manners writ large in the language of political philosophy?"49 Perhaps it was a sensitivity to this sort of criticism that led the Supreme Court of Canada to backtrack from Keegstra's emphasis on the emotional trauma of hate speech - an emphasis that was arguably exaggerated in that case because of the Court's failure to provide any evidence of the degree of emotional trauma actually caused by Keegstra's anti-Semitic tirades. Given the absence of any evidence that criminalizing hate speech actually does anything to promote peoples' equal standing in society's major institutions, particularly in the context of contemporary Western democracies, the better approach for both Waldron and the Court might well have been to bite the liberal bullet and defend the propriety of sending people to prison in the name of "Miss Manners writ large."

Naturally, an account along these lines would yield a very different explanation of the harm in hate speech. Rather than attempting to secure the fragile public good of assurance (or, as the Court puts it in Whatcott, "societal standing"), hate speech legislation would be understood as protecting private interests against offense; rather than inquiring into the

\footnotetext{
46 Ibid at 1,84 .

47 Ibid at 84.

48 Whatcott concerned non-criminal sanctions under Saskatchewan's human rights code. But Whatcott leaves untouched Keegstra's earlier holding that criminal sanctions are justified under s. 1 of the Charter as a means of regulating hate speech.

${ }^{49}$ Brian Leiter, Book Review of The Harm in Hate Speech by Jeremy Waldron, online: (2012) Notre Dame Philosophical Reviews <http://ndpr.nd.edu/news/32077-the-harm-in-hate-speech/ >.
} 
aggregate impact of individual acts of hate speech upon egalitarian assurance, we would instead inquire into the specific impact of each instance of hate speech upon some concrete person's interest in not being offended or psychologically traumatized. Whether this is an attractive account of the scope of the right to free expression in a liberal society is, of course, another question entirely. ${ }^{50}$

\section{III.}

Alon Harel has recently articulated a broader, more general version of the type of argument I have so far been considering. Harel argues that we ought to recognize a duty to criminalize certain forms of conduct - indeed, a duty of constitutional significance regardless of whether criminalization does anything to drive down the incidence of the targeted conduct. This is because, Harel argues, by criminalizing conduct we are saying publicly that certain courses of conduct are not within the set of permissible options that a person may choose from. Drawing on Philip Pettit's work in republican political theory, Harel argues that by criminalizing conduct, we expand the scope of each individual's dominion over how his or her life goes - we ensure that people are not subject to the potentially capricious judgment of others to interfere in their lives. ${ }^{51}$ Through criminalizing conduct, we remove ex ante the discretion to assault, attack or violate others - that is, the discretion to do so conditioned on payment of adequate compensation ex post. Even if criminalizing assault does nothing for the incidence of assault, it at least indicates that third parties are not at liberty to assault you, even if they are willing and able to pay damages afterwards. ${ }^{52}$

${ }^{50}$ A recent op-ed in one of Toronto's major daily newspapers, the Toronto Star, referred to former United States vice-president Dick Cheney as a "war criminal," implied that he was both a crank and a coward, likened his policies to those of the "Nazis and Japanese," stated that "[t]he world has become measurably more awful" because of his actions and that he has eluded justice because of his wealth, before ending by calling Cheney "a terrible man, a slab of congealed venom who has brought misery and pain to every aspect of American governance he has been allowed to touch since 1969," and a "dead man[]" who is "floating in the blood of others." Heather Mallick, "The malign Dick Cheney is visiting Toronto," Editorial, Toronto Star (29 October 2013) online: http://www.thestar.com/opinion/commentary/2013/10/29/the_malign_dick_cheney_is_visiting_t oronto_mallick.html.

If Tea Party politicians have a right to recover after being called "liars," it seems that Waldron must take the view that the Toronto Star ought not have been permitted to run this editorial; Cheney ought to have been able to enjoin its publication as an assault on his dignity, and perhaps also to recover monetary damages after the fact. Notably, the author of the editorial was arguing that Cheney should be denied entry into Canada (where he had been invited to give a lecture), and was thus directly attacking Cheney's social and legal status, not just his beliefs and policies.

51 Harel, "The Duty to Criminalize" [unpublished MS, page 5]. Harel thinks of this duty as "constitutional." I will not go into Harel's reasons for thinking this; for discussion, see Alon Harel, Why Law Matters (Oxford: Oxford University Press, forthcoming 2014), ch. 5 ("Why Constitutional Rights Matter.")

52 See Pettit, supra note 1 at 83: "people should have a publicly established and acknowledged status in relation to others; only this could enable them to walk tall and look others in the eye. 
Increasing the scope of citizens' dominion is undoubtedly a goal that egalitarians can get behind, particularly when what is at issue is dominion over basic aspects of one's life bodily integrity, sexual autonomy, stable property expectations and the like. However, Harel's proposal conflates enhancing citizens' actual dominion with enhancing citizens' perception of dominion. Criminalizing assault enhances dominion insofar as it contributes to decreasing the willingness of third parties to engage in that kind of conduct, in turn enhancing citizens' actual ability to go about their lives free from that kind of arbitrary interference, not merely their perception of that freedom. Suppose, for instance, that society A and society B have equivalent rates of armed robbery, but that society A treats armed robbery as a crime and society B treats it as a tort, i.e. as protected by a liability rule requiring ex post compensation. Insofar as the criminal penalties society A imposes for armed robbery deprives those individuals of dominion - for instance, by making them subject to the arbitrary whims of prison wardens and parole boards - citizens in society A have, overall, less dominion over their lives than citizens in society B. This is despite the fact that society A describes armed robbery - surely an act of arbitrary interference - as a crime while society B does not. One might speculate that citizens in society B would suffer from a generalized fear that one could be violently deprived of one's property at any time, whereas those in society A would not. But there would be no rational ground for this fear in society $\mathrm{B}$ that does not also exist in society $\mathrm{A}$, on the assumption that rates of armed robbery are in fact equivalent in both societies. In this stylized example, society B is preferable to society A from the point of view of an egalitarian distribution of dominion.

Now, it is true that relying solely on a compensation scheme for criminal injuries does not publicly convey that it is not within a private party's discretion to assault another, and in that sense may make it seem as though it remains free for individuals to assault each other at will, so long as they are ready to pay the price later. But this is just so much window-dressing. After all, nothing prevents private parties from understanding criminal sanctions to be prices as well. ${ }^{53}$ What is important is not whether it seems to private parties that it is, or is not, within their discretion to interfere in the lives of others, but rather whether appropriate steps are taken to actually discourage such interference. It is entirely plausible that in many cases criminal sanctions will do better at securing this level of protection than non-criminal sanctions, particularly when large segments of the population are effectively judgment-proof. This provides a reason to criminalize conduct that constitutes an arbitrary interference in the lives of others. But this reason is not grounded in the need to publicly avow that citizens have dominion over their lives, but in the need to provide actual, substantive dominion. It is, in other words, a reason to criminalize based squarely on protection of first-order interests rather than, as Harel's proposal would have it, on a second-order interest in the public avowal of the importance of one's first-order interests.

Within the sphere of those liberties people should be entrenched on a public basis against the incursions of others. They ought to enjoy objective safeguards that apply regardless of the will of others as to how they should choose in that domain. And it ought to be a matter of shared awareness in the society that they are so guarded."

53 Uri Gneezy \& Aldo Rustichini, “A Fine is a Price” (2000) 29:1 J Legal Stud 1. 
Once again, I stress that this is not to say that second-order interests are unimportant. Waldron's characterization of assurance as a form of public good is apt; as with clean air or fresh water, it is undeniably of great significance that individuals are able to assume, correctly and without conscious reflection, that they will not face discrimination, harassment and animosity in the major institutions of civil society. Nor do I mean to deny that there is a role for public institutions to play in promoting second-order interests. Corey Brettschneider has recently argued, for instance, that a liberal state may permissibly condemn wrongful or hateful conduct publicly and expressively, even while it protects the rights of those who engage in such conduct, a view that Brettschneider refers to as "value democracy." Brettschneider suggests that "we distinguish between a state's coercive power, or its ability to place legal limits on hate speech, and its expressive power, or its ability to influence beliefs and behavior by 'speaking' to hate groups and the larger society." According to Brettschneider, the state "should simultaneously protect hateful viewpoints in its coercive capacity and criticize them in its expressive capacity." 54 Brettschneider identifies a variety of means by which the state may seek to rationally change the beliefs and attitudes of illiberal dissentients: through the state's role as public educator, through subsidies, grants and tax exemptions to private groups promoting egalitarian and liberal ideals, by establishing monuments and public holidays, speeches and statements by politicians, and through appellate court opinions. ${ }^{55}$ Although hate groups are entitled to express their grievances, no one's views are entitled to successfully carry the day or to be immune from critique. Insofar as the beliefs and attitudes expressed are inconsistent with the ideal of free and equal citizenship, the state may seek to change them via a process of rational persuasion - of publicly explaining, as Brettschneider puts it, the "reasons for rights." 56

By distinguishing the state's role in communicatively defending egalitarian ideals and its role in applying coercive sanctions, value democracy accommodates a significant role for the state in promoting the second-order interests described by Waldron and Harel. ${ }^{57}$ When the state speaks, it should seek to affirm and deepen its citizens' understanding of the reasons for rights. But when the state turns from speech to the invasion of first-order interests, its focus should be on whether such coercion is reasonably required in order to make good on its guarantee that each person under its jurisdiction has his or her first-

54 When the State Speaks, What Should it Say? (Princeton: Princeton University Press, 2012) at 3. See especially ch 3.

55 Ibid ch $3 \& 4$.

56 Ibid at 86.

57 Criminal sanctions are a proper subset of coercive sanctions. Coercion for Brettschneider occurs when "the state threaten[s] to impose a sanction or punishment on an individual or group of individuals with the aim of prohibiting a particular action, expression, or holding of a belief." Ibid at 88. Value democracy thus supports a more restrictive account of the permissible means for the promotion of second-order interests than the argument from egalitarianism, which rules out only criminal sanctions, i.e. sanctions that seriously invade a person's first-order interests. On the other hand, by predicating the argument on invasions of interests rather than coercion, the argument from egalitarianism avoids the rather sticky issue of determining what "the" aim of any given state action is. 
order interests adequately protected; for, by the lights of NCE, this is the core commitment of equal respect and concern. ${ }^{58}$

\section{IV.}

Harsh, even ultra-harsh, sanctions are likely to be practically unavoidable as a means of propping up a society's basic institutions, and therefore practically unavoidable as a means for protecting the allocation of rights, interests and capabilities that those institutions create. No doubt there is symbolic importance in how these sanctions are used, and no doubt no full accounting of coercive state power can afford to ignore the salience of political symbolism. Nevertheless, theorists who wish to domesticate the rather less pleasant aspects of a Hobbesian view of state power ought not be too quick to appeal to political symbolism as a justification for invading a person's first-order interests. Insofar as criminal sanctions are suspect because of the setbacks they inflict on people's first-order interests, they should be viewed as themselves derogations from the fundamental egalitarian norm of equal respect and concern. It may nevertheless be permissible or even obligatory to impose such sanctions, but this should only be on the condition that doing so is itself justifiable in egalitarian terms.

\footnotetext{
58 State regulation, even coercive regulation, extends well beyond first-order interests. Insofar as those regulations need criminal sanctions as a final backstop for compliance purposes - the paradigmatic case is contempt of court - there is an important role for criminal sanctions in promoting institutional stability, even when those institutions are not themselves directly protective of first-order interests. This is an important distinction between Taylor, supra note 17, in which the accused were charged with ignoring an order from Canada's federal human rights tribunal requiring them to shut down their white supremacist phone service, and Keegstra, supra note 9 , in which the accused were charged directly with willfully promoting hatred in violation of the Criminal Code. Whether there is a plausible justification for imposing criminal sanctions in these kinds of cases depends, I suggest, on whether it is plausible to construe an interest in selfgovernment through stable institutions as itself a first-order interest.
} 